\title{
Albertans to gain electronic access to personal health files
}

Published at www.cmaj.ca on May 28

A lberta, already a leader in Canada in connecting health professionals to electronic information systems, is gearing-up to bring patients into the loop.

And that, says the province's health minister, will radically change the way Albertans get health care.

Starting this fall, says Gene Zwozdesky, Alberta's Minister of Health and Wellness, the province will introduce an Internet-based system that will provide Albertans with access to a "personal health portal" through which they can tap their own personal health records (PHRs).

While several nations and health management agencies around the world already offer tens of millions of people access to their personal health records, only Alberta appears on a fast track toward doing so in Canada. In fact, a $C M A J$ canvas indicates that in nearly all provinces and territories, personal health records are a nonstarter.

But Zwozdesky says Alberta has a concrete strategy to connect patients to the province's already-robust system of electronic health records.

"Albertans have told us for a long time that they want electronic health records that will empower them," Zwozdesky says, explaining that "at the moment, the electronic health record system is just for health professionals. Now, we are getting requests from citizens saying we want this to be a twoway street; we want to know more about ourselves as well. And that's what we are working on."

Patients will be connected in three stages.

In September, the province will rollout an extensive system of Internet-based information platforms for Albertans seeking health information and information about provincial heath care services.

Once that's operational, patients will be given the opportunity to connect to the electronic health record system through an Internet portal that will provide them access to their health files, including prescription histories, lab test results and diagnostic imaging results.

A third phase would allow patients to directly interact with the health care system by, for example, booking health services appointments online.

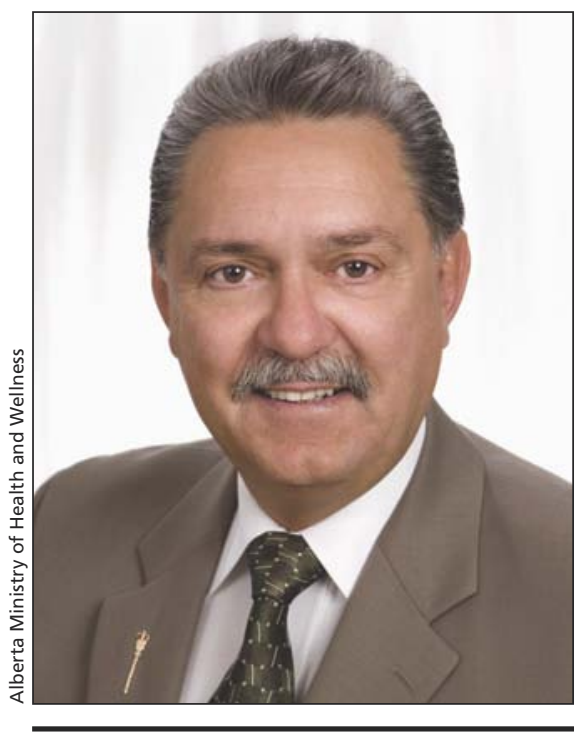

Providing Albertans with electronic access to their personal health records "is too important for us to wait," says Minister of Health and Wellness Gene Zwozdesky.

"All of this is to provide faster, better, health care and maximize health professionals' time," Zwozdesky says. "People are genuinely excited about the new things that we can do to improve health care and make it more efficient, more timely, more relevant. Albertans are becoming more and more proactive about maintaining their own health.'

Although access to electronic PHRs has long been described as a key tool in cutting systemic costs and improving patients' health by enabling them to "self-manage" chronic conditions such as hypertension and diabetes, Canadian efforts to introduce electronic access have seriously lagged behind those of Europe and the United States.

A CMAJ survey of Canada's 13 provincial and territorial health ministries indicates that only Alberta has firm plans to introduce PHRs, although Quebec has placed a foot on that trail by launching a pilot project to test a privately developed PHR system.

Ontario's plans appear somewhat nebulous. "There are things underway but we're not in a position to talk about them," says eHealth Ontario spokeswoman Heather Brown. "Management is still trying to conceptualize what [a PHR] would look like."

The remaining provinces and territories say their residents will simply have to wait while Alberta sails ahead.

"While PHRs are not in our plans today, Manitoba will be monitoring other provinces and adopt any best practices that emerge," Roger Girard, Manitoba eHealth's Chief Information Officer, writes in an email.

Nor does it appear that the federal government will soon prod provinces and territories to adopt PHRs. While the federal government has invested $\$ 2.1$ billion in the development of a national health infostructure since 2001, Canada Health Infoway Inc. has never directly invested in PHR projects.

Ron Parker, group director of solutions projects for the agency, says a national PHR system is being envisioned but remains at a discussion stage.

"If we don't plan for it and we don't have the vision to do it, we won't understand what we need to do now," he says, while cautioning that federal investment in PHRs will not happen soon.

Rather than wait for matching funds from the federal government, Alberta decided to proceed on its own, Zwozdesky says.

"I am going to be meeting with the federal minister of health and with all the health ministers from the provinces and territories in September, and there are a few of these dominion-wide issues that we need to talk about in order to get on the same page," he says. "But in the meantime, this is too important for us to wait."

Canada's slow progress toward the PHR onramp will eventually result in a consumer backlash, several experts say.

"Groups, mainly led by patients, are now beginning to take matters into their own hands to address problems that the 
health system has continued to ignore," says Alex Jadad, founding director of the Center for Global eHealth Innovation at the University of Toronto in Ontario. "Instead of conforming to the traditional asymmetrical offline patientphysician relationship, the public is embracing the [Internet], opening new horizons for a level playing field and improved health services."

Consumer demand will only increase, says Marc Filion, chief operating officer and general manager for the Quebec-based TELUS Health Solutions, which recently acquired an exclusive Canadian licence for a PHR software package developed by multinational computer giant Microsoft Corporation.

Consumer demand for "tools that enable patients to manage their own health care," is set to grow rapidly, says Filion. - Paul Christopher Webster, Toronto, Ont.

DOI: $10.1503 /$ cmaj.109-3270
Ninth in a series on electronic health records.

Part I: Canada's electronic health records initiative stalled by federal funding freeze (CMAJ 2010: DOI:10.1503/cmaj.109-3183)

Part II: Ontario's plan for electronic health records is at risk, official says (CMAJ 2010: DOI:10.1503/cmaj.109-3193)

Part III: Electronic health records a "strong priority" for US government (CMAJ 2010: DOI:10.1503/cmaj.109-3218)

Part IV: The pocketbook impact of electronic health records: PRO (CMAJ 2010: DOI:10.1503/cmaj.109-3225)

Part V: The pocketbook impact of electronic health records: CON (CMAJ 2010: DOI:10.1503/cmaj.109-3226)

Part VI: National standards for electronic health records remain remote (CMAJ 2010: DOI:10.1503/cmaj.109-3239)

Part VII: National electronic health records initiative remains muddled, auditors say (CMAJ 2010: DOI:10.1503/cmaj.109-3242)

Part VIII: New electronic health record blueprint to call for increased patient participation (CMAJ 2010: DOI:10.1503/cmaj.109-3265) 